\title{
SUSTAINABILITY ACCOUNTING AND REPORTING AT A SECTOR LEVEL: MAPPING THE TERRAIN
}

\author{
Aideen O'Dochartaigh and Rebecca Maughan \\ Quinn School of Business, University College Dublin, Dublin 4
}

\begin{abstract}
$\mathrm{T}$

The aim of this paper is to develop our understanding of accounting and reporting for sustainability at a sector level, an area where there is a significant deficit of literature. As sustainability is a system-based concept, there is a growing recognition that sustainability reporting needs to move beyond single-entity reports towards multiple organisation reporting, such as industry, supply chain and sector-level reports. However, few studies have explored the challenges and possibilities of multiple organisation reporting, and no established sector-level reporting guidelines exist. This study advances the sustainability accounting literature by mapping the field of multiple organisation sustainability reporting, drawing together any existing literature and reviewing emerging voluntary reporting mechanisms. We identify different levels of sustainability parameters and reporting: global, national, sectoral, organisational and product. We then evaluate emerging reporting frameworks at a sectoral level, with reference to the agri-food sector, an industry with significant ecological impacts. We review these frameworks, along with a practitioner example of sustainability reporting at a sectoral level in the form of Bord Bia's Origin Green programme, in the context of global sustainability parameters, namely planetary boundaries and the Sustainable Development Goals. In doing so we identify a lack of coherent linkages among these global parameters of sustainability and emerging reporting frameworks and reporting. We suggest directions for future research by which these gaps may be addressed.
\end{abstract}




\section{INTRODUCTION}

Traditional reporting and accountability places at its centre the 'economic organisation' (the entity concept) and assumes it will continue indefinitely (the going concern concept). Sustainability, however, requires a collective and cumulative assessment of economic activity relative to a resource base. Organisation-based assessment and reporting, then, no matter how well extended with social and environmental impact information, will not be sufficient to demonstrate sustainability if it fails to consider the cumulative effect of all activity - and therefore quite probably multiple organisations - on the carrying capacity of given ecosystems.

(Gray and Milne, 2002, p. 3; emphasis added)

Accounting scholars are increasingly engaged with sustainability (Bebbington et al., 2014; Burritt and Schaltegger, 2010), and sustainability accounting and reporting is of growing interest to practice; 92 per cent of the world's top 250 companies now produce a sustainability report (KPMG, 2015), and from FY2017, the new EU NonFinancial Reporting Directive will require EU companies with over 500 employees to disclose social and environmental data. Accounting is an entity-based concept, and the sustainability accounting and reporting literature has focused largely on single entities. Sustainability, however, is a system-based concept, better understood economically at the level of multiple rather than single entities (Gray, 2010). To date, little is known in practice or in the literature about the challenges and possibilities of reporting at the level of multiple organisations. Although entity sustainability reports are numerous, sector-level or supply chain reports are rare, and no established guidelines exist for multiple organisation sustainability reporting.

In addition, persuasive evidence from the natural sciences suggests that human activity is threatening the carrying capacity of the Earth system (Steffen et al., 2015). There is an increasing recognition that to contribute substantively in this area, sustainability accounting and reporting research must move from a single entity to a multiple organisation focus and engage with sustainable development science, in particular, global parameters such as planetary boundaries (Gray, 2010; Bebbington and Larrinaga, 2014; see also Whiteman et al., 2013). The two planetary processes that are most beyond boundary limits are biodiversity loss and the nitrogen cycle (Bebbington and Larrinaga, 2014, p. 401). The implications of the nitrogen cycle have yet to be translated into organisational research, and Bebbington and Larrinaga (2014, p. 401) suggest that area where one would make the connection (in operational terms) to the nitrogen cycle is through research focused on the farming industry or food.

In an Irish context, the agri-food sector is the country's most greenhouse gas (GHG)-intensive sector, responsible for 33 per cent of annual GHG emissions (EPA, 2016). It is also crucial to the economic and social fabric of Ireland, accounting for 11 per cent of total exports and supporting 250,000 jobs (Careers Portal, 2017). Sustainability is an increasing concern within the sector (EPA, 2016), and Bord Bia, the semi-state body responsible for the international promotion of the Irish agrifood sector, has recently launched its Origin Green sustainability programme for the industry, publishing Sustainability Reports in 2015 and 2016. On this basis, we 
consider this an opportune time to analyse emerging sustainability guidelines and reporting for this sector. This paper seeks to map the terrain of sector-level sustainability accounting and reporting and analyse the linkages between emerging guidelines for sector-level sustainability reporting, Bord Bia's Origin Green report and planetary boundaries. In doing so the study provides insight into the potential of sector-level reporting to advance the field of sustainability reporting.

The paper is structured as follows: first, we identify and review the existing literature on accounting for sustainability at the multiple organisation level. After a discussion of research methods, we analyse sustainability parameters at global, national, organisation and product level. We then narrow our focus to the sectoral level, specifically the agri-food sector, analysing emerging guidelines for sustainability reporting and the Origin Green report, with reference to planetary boundaries and the UN Sustainable Development Goals (SDGs). Finally, we consider the implications of our analysis for the sustainability accounting and reporting field and suggest some avenues for future research.

\section{ACCOUNTING FOR SUSTAINABILITY IN MULTIPLE ORGANISATIONS}

Research on accounting for social and environmental issues has grown steadily since early work on social audit (e.g. Medawar, 1976) and environmental accounting (e.g. Ullmann, 1976). Several methods of environmental accounting at an organisational level have been developed, such as full-cost accounting (Herbohn, 2005), the sustainable cost calculation (Bebbington and Gray, 2001) and the Sustainability Assessment Model (Bebbington, 2007). There has also been considerable work analysing stand-alone reporting (see Thomson, 2014, and Parker, 2005, for reviews). Single-entity social and environmental disclosure has been analysed through the lenses of, inter alia, accountability (e.g. Gray, 2006), legitimacy (e.g. Deegan et al., 2002; Milne and Patten, 2002; O'Dwyer, 2002) and stakeholder theory (e.g. Gray et al., 1997; Rinaldi et al., 2014). In addition, there is an extensive literature on content analysis (see Fifka, 2013, and Guthrie and Abeysekera, 2006 for reviews) and a growing body of work analysing the discourse and rhetoric of stand-alone reports (e.g. Milne et al., 2009; Tregidga et al., 2014).

Very little of this work, with a few exceptions (Georgakopoulos and Thomson, 2008; Russell and Thomson, 2009; and Spence and Rinaldi, 2010, 2014), goes beyond a single-entity focus. However, single-entity actions and measurement may not be sufficient to address systemic sustainability challenges (Gray and Milne, 2002; Whiteman et al., 2013). The nature of sustainability, as Gray and Milne (2002) argue, is such that it must be conceptualised at a system level, which means considering the cumulative effect of multiple organisations on ecological and social systems. Measures of sustainability at a global level, such as planetary boundaries (ecological) and the UN's SDGs (social and ecological), require an engagement with the concept of multiple organisation activity, for example at a supply chain or sectoral level. While we do not observe a distinct body of literature on accounting for sustainability at the level of multiple organisations, a small number of scholars, namely Georgakopoulos and Thomson (2008), Russell and Thomson (2009) and 
Spence and Rinaldi (2010, 2014), have conducted valuable studies in which they consider reporting beyond a single organisation.

Russell and Thomson (2009) explore the possibility of accounting for a 'sustainable Scotland'. They argue that accounting can be used to make aspects of sustainability 'thinkable' and 'governable', an observation which suggests that there is potential for more powerful actors within a sector to use the sustainability accounting process to change the behaviour of other actors.

Georgakopoulos and Thomson (2008) examine social reporting in the salmon farming industry, mapping the reporting 'arena' and interviewing constituent stakeholders. They find that the social reports of the salmon farming organisations 'were designed to allow others to monitor compliance with voluntary and regulatory standards' and that social reporting practices are 'explained by power differentials' (Georgakopoulos and Thomson, 2008, pp. 1136-1137). For example, the Scottish Salmon Grower's Association, an industry body, gathered data on behalf of its members and used the ensuing reports to, among other things, lobby for regulatory reform. Georgakopoulos and Thomson suggest that the association was addressing what it saw as a 'power imbalance' between the producer organisations and the political institutions and rule enforcers.

Spence and Rinaldi $(2010,2014)$ examine the efforts of a large supermarket to govern sustainability issues in its lamb supply chain. Their work reveals a number of challenges of reporting at a multiple organisation level, including the complexity of the supply chain (involving multiple participants, not just the farmer and supermarket), the power relations between these participants, and the supremacy of commercial priorities.

While these studies do not tell us about the content and structure of 'accounts' of sustainability at the level of multiple organisations, they offer some valuable insight into the related complexities. Each study highlights the power relations between the different organisations involved, and this suggests that considerable negotiation would be involved in sector-level sustainability reporting, making it significantly more challenging than single-entity reporting. In mapping the field of sector-level sustainability reporting, our study will add further insight to this small body of literature, providing guidance for researchers seeking to analyse and evaluate emerging sector-level sustainability reports.

In addition to our limited understanding of multiple organisational reporting, Bebbington and Larrinaga (2014, p. 401) suggest that the issues considered in social and environmental accounting ' are those that are most closely related to operational concerns of large for-profit entities' and accounting researchers have 'insufficient exposure to the ecological concerns that emerge from the sustainable development field' (Bebbington and Larrinaga, 2014, p. 401). These sentiments echo those of other scholars who suggest that management and accounting researchers must engage more substantively with the complex and urgent concerns of sustainable development (e.g. Gray, 2010; Milne and Gray, 2013; Dyllick and Muff, 2016). Therefore, although we are conscious of the extensive body of prior literature on social and environmental accounting and reporting in organisations, we draw on Bebbington and Larrinaga's (2014, pp. 397-398) argument 'that accounting for sustainable development implies a research approach that is distinctively different from that 
of accounting, environmental accounting and social accounting'. Following Bebbington and Larrinaga (2014, p. 401), we wish to situate our work in the field of accounting for sustainable development and to take concerns from the field of sustainable development, specifically the nine planetary boundaries (modelled in Figure 1 identified by Rockstrom et al., 2009), as the departure point for this study.

FIGURE I: CONCEPTUALISING SECTOR-LEVEL SUSTAINABILITY: LAYERS OF IMPACT

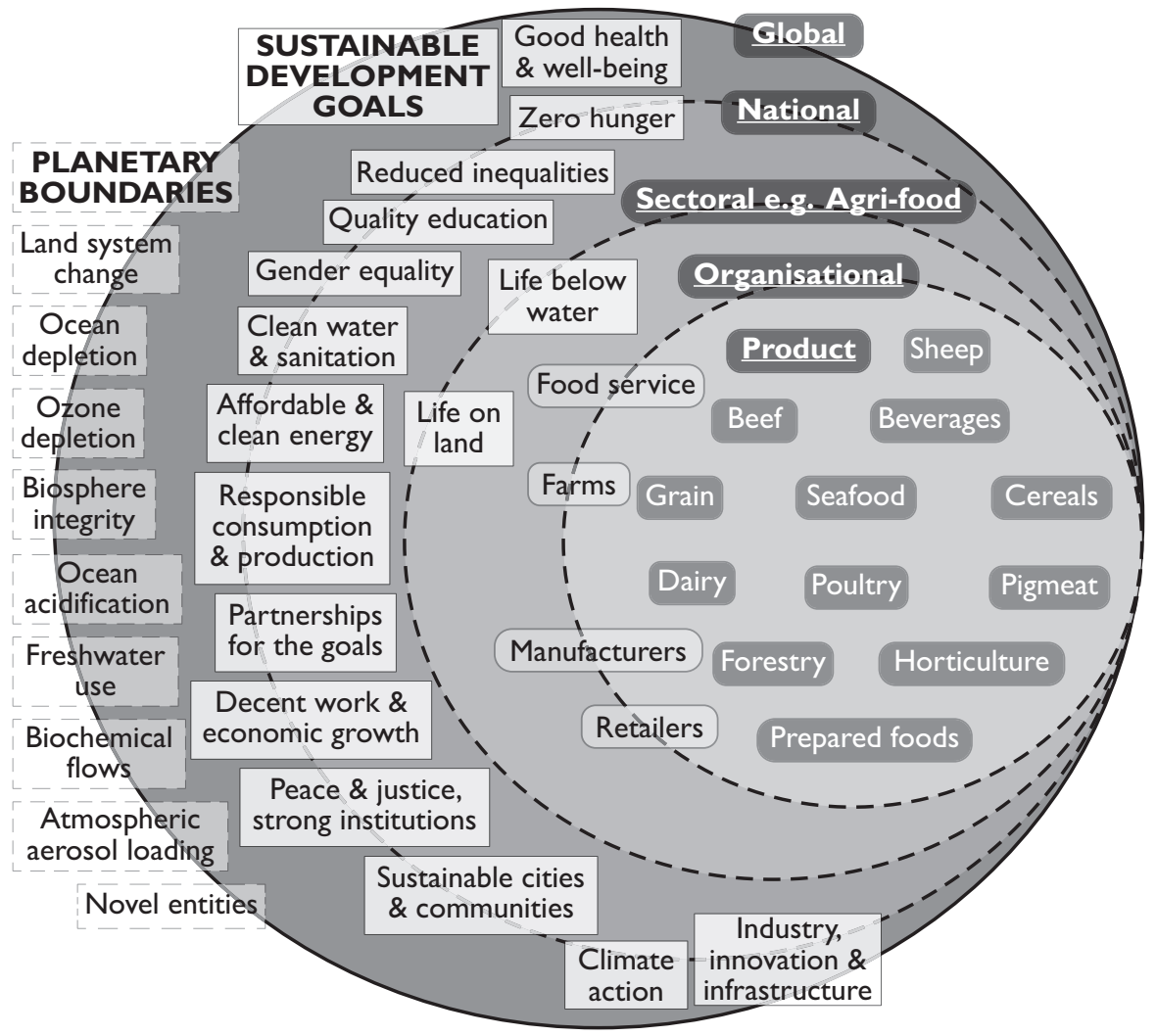

The two planetary processes that are most beyond boundary limits are biodiversity loss and the nitrogen cycle (Bebbington and Larrinaga, 2014, p. 401). There is an emerging accounting literature on biodiversity; however, the implications of the nitrogen cycle have yet to be translated into organisational research (Bebbington and Larrinaga, 2014, p. 401). Bebbington and Larrinaga (2014, p. 401) suggest that the area where one would make the connection (in operational terms) to the nitrogen cycle is through research focused on the farming industry or food. Using Origin Green as our operational anchoring point, this paper contributes to the literature on sustainability reporting by analysing the linkages or lack of linkages between the Origin Green report, emerging guidelines of sustainability reporting in the agrifood sector and planetary boundaries. 


\section{RESEARCH METHODS}

A range of documentary data related to measuring and reporting on sustainability or accounting for sustainable development was analysed for the study. ${ }^{1}$ Guided by Bebbington and Larrinaga (2014), we began our documentary data collection by engaging with the sustainability science literature, and in particular with planetary boundaries (Rockstrom et al., 2009). As the section 'Sustainability Indicators and Reporting Guidelines' discusses, we examined how sustainability parameters have been identified in the natural sciences literature and applied at global and national levels (e.g. Fang et al., 2015b; Lammers et al., 2008). The documentary data collection was also guided by the literature related to sustainability indicators at an organisational level, the sustainability accounting literature (e.g. Bebbington and Gray, 2001; Bebbington et al., 2001), and work on product life-cycle assessment (e.g. ISO14044; Bjorn et al., 2016). In addition, reflecting our focus on the agri-food sector, we searched for data related to sustainability reporting in this sector.

As Table 1 illustrates, typical documents collected were reports produced by regulatory/standard-setting bodies such as the EU, UN and OECD, and academic studies in the ecological economics and sustainability accounting areas. Google searches were also conducted for terms such as 'sector-level sustainability reporting' or 'supply chain sustainability accounting'. The documents analysed included existing reporting guidelines such as the G4 Global Reporting Initiative (GRI) Guidelines and projects in progress at a policy level such as the EU's Organisation and Product Environmental Footprint pilots. To select the documents for analysis, we searched for literature in four categories:

\section{TABLE I: DOCUMENTARY DATA RELATING TO EXISTING SUSTAINABILITY REPORTING GUIDELINES AND FRAMEWORKS}

\section{Existing single-entity reporting standards}

Global Reporting Initiative (GRI) (20I6). GRI Standards, available from: <https://www. globalreporting.org/standards>, accessed 5 December 2016 [Registration Required].

International Organisation for Standardization (ISO) (2016). ISO 26000:2010(en) Guidance on Social Responsibility, available from: <https:/www.iso.org/obp/ui/\#iso:std:iso:26000:ed-l:vl:en>, accessed 5 December 2016 [Purchase Required].

United Nations Global Compact (2016). The Ten Principles of the United Nations Global Compact, available from: <https://www.unglobalcompact.org/what-is-gc/mission/principles>, 5 December 2016.

\section{Academic studies}

Bebbington, J. (2007). Accounting for Sustainable Development Performance, Oxford: CIMA.

Bebbington, J. and Gray, R. (200I). An Account of Sustainability: Failure, Success and a Reconceptualization, Critical Perspectives on Accounting,Vol. I2, No. 5, pp. 557-587.

Ekins, P., Simon, S., Deutsch, L., Folke, C. and De Groot, R. (2003). A Framework for the Practical Application of the Concepts of Critical Natural Capital and Strong Sustainability, Ecological Economics, Vol. 44, No. 2, pp. 165-185. 
TABLE I: (CONTINUED)

Fang, K., Heijungs, R. and De Snoo, G.R. (20I5a). Understanding the Complementary Linkages Between Environmental Footprints and Planetary Boundaries in a Footprint-Boundary Environmental Sustainability Assessment Framework, Ecological Economics, Vol. I I4, pp. 218-226.

Figge, F. and Hahn, T. (2004). Sustainable Value Added-Measuring Corporate Contributions to Sustainability Beyond Eco-Efficiency, Ecological Economics,Vol. 48, No. 2, pp. I73-187.

Herbohn, K. (2005). A Full Cost Environmental Accounting Experiment, Accounting, Organizations and Society, Vol. 30, No. 6, pp. 519-536.

Hess, T.M., Chatterton, J. and Williams, A. (2012). The Water Footprint of Irish Meat and Dairy Products, Cranfield University.

Hoekstra, A.Y. and Wiedmann, T.O. (20I4). Humanity's Unsustainable Environmental Footprint, Science,Vol. 344, No. 6188, pp. III4-1 II 17.

Obst, C.G. (2015). Reflections on Natural Capital Accounting at the National Level:Advances in the System of Environmental-Economic Accounting, Sustainability Accounting, Management and Policy Journal,Vol. 6, No. 3, pp. 3I5-339.

Pretty, J., Smith, G., Goulding, K.W.T., Groves, S.J., Henderson, I., Hine, R.E., King,V., Van Oostrum, J., Pendlington, D.J.,Vis, J.K. and Walter, C. (2008). Multi-Year Assessment of Unilever's Progress towards Agricultural Sustainability I: Indicators, Methodology and Pilot Farm Results, International Journal of Agricultural Sustainability, Vol. 6, No. I, pp. 37-62.

Wackernagel, M., Onisto, L., Bello, P., Linares, A.C., Falfán, I.S.L., Garcla, J.M., Guerrero,A.I.S. and Guerrero, M.G.S. (1999). National Natural Capital Accounting with the Ecological Footprint Concept, Ecological Economics, Vol. 29, No. 3, pp. 375-390.

\section{Emerging guidelines}

EU (2008). Sustainable Consumption and Production and Sustainable Industrial Policy Action Plan Council Conclusions. Brussels: Council of the European Union.

EU (2016). OEF Retail Data Collection Template, available from:<https://webgate.ec.europa.eu/ fpfis/wikis/display/EUENVFP/Stakeholder+workspace\%3A+OEFSR+pilot+Retail>, accessed 5 December 2016 [Registration Required].

EU (2017). The Environmental Footprint Pilots, available from: <http://ec.europa.eu/environment/ eussd/smgp/ef_pilots.htm>, accessed 7 February 2017.

Natural Capital Coalition (2016). Natural Capital Protocol: Food and Beverage Sector Guide. Natural Capital Coalition, available from: <http://naturalcapitalcoalition.org/wp-content/uploads/2016/07/ NCC_FoodAndBeverage_WEB_2016-07-12.pdf>, accessed 6 December 2016.

UNFAO (Food and Agriculture Organisation of the United Nations) (2016). System of Environmental-Economic Accounting for Agriculture, Forestry and Fisheries - SEEA Agriculture CONSULTATION DRAFT, available from: < https://unstats.un.org/unsd/envaccounting/aff/2GC_ Draft.pdf>, 8 December 2016.

\section{Quantitative data}

OECD (2013a). 2013 Edition of the OECD Environmental Database: Data for Ireland, available from: <http://stats.oecd.org//Index.aspx?Queryld=48648>, accessed 7 December 2016.

OECD (20I3b). Food Waste, available from: <https://stats.oecd.org/Index.aspx?DataSetCode= FOOD_WASTE>, accessed 7 December 2016.

OECD (2017). Generation of Waste by Sector, available from: <https://stats.oecd.org/Index.aspx? DataSetCode=WSECTOR $>$, accessed 24 February 2017. 
- Existing single-entity reporting standards.

- Academic studies linking accounting and sustainability science for example studies on ecological footprint accounting, accounting for planetary boundaries, natural capital accounting. In particular, we searched for studies relevant to the agri-food sector.

- Emerging guidelines for sustainability reporting at a multiple organisation level, particularly in the agri-food sector.

- Quantitative data relating to the environmental impact of the agri-food sector.

The next section presents our review of the documentary data collected. This analysis, coupled with the review of the sustainability accounting literature detailed in the 'Accounting for Sustainability in Multiple Organisations' section, indicated that there are no established guidelines for sector-level sustainability reporting, and little work analysing how the emerging guidelines may or may not link to higherlevel parameters like the planetary boundaries and the UN SDGs.

\section{SUSTAINABILITY INDICATORS AND REPORTING GUIDELINES}

How to define and measure sustainability is the subject of continuing debate (e.g. Bansal and Song, 2017; Montiel and Delgado-Ceballos, 2014), and there are myriad ecological and social indicators at a planetary level, many generated by international bodies such as the UN (e.g. UNMEA, 2004; UNDP, 2015; UNEP, 2016) and environmental NGOS (e.g. Worldwatch Institute, 2013; WWF, 2016). As discussed in the 'Accounting for Sustainability in Multiple Organisations' section, we find the concept of 'planetary boundaries', a comprehensive contemporary measure of the Earth's carrying capacity developed by Rockstrom et al. (2009) and updated by Steffen et al. (2015), a useful point to begin our analysis.

Rockstrom et al. (2009) identify nine ultimate planetary boundaries, scientific measures of ecological degradation such as ozone depletion and ocean acidification which, if breached, could threaten the resilience of the Earth system. The planetary boundaries are natural processes that are being affected by human action. Steffen et al. (2015) show that two of these boundaries are already in the high-risk zone: biosphere integrity and biochemical flows. The nine planetary boundaries are:

- Stratospheric ozone depletion $-\mathrm{O}_{3}$ concentration in the stratosphere, which has been reducing as the ozone hole is repairing

- Biosphere integrity - biodiversity loss and extinctions

- Novel entities - new substances or new forms of existing substances introduced by humans for example plastic polymers, chemicals such as chlorofluorocarbons (CFCs)

- Climate change - atmospheric concentration of $\mathrm{CO}_{2}$

- Ocean acidification - change in ocean $\mathrm{pH}$ caused by $\mathrm{CO}_{2}$ concentration 
- Freshwater use - freshwater consumption and changes to the global hydrological cycle

- Land system change - land converted for human use and its function for example agricultural, residential

- Biochemical (nitrogen and phosphorus) flows to the biosphere and oceans

- Atmospheric aerosol loading - atmospheric aerosol pollution, measured by aerosol optical depth

A number of scholars have suggested that management and accounting scholars must begin to engage with the planetary boundaries framework, but acknowledge that this is challenging, as system-level indicators of sustainability like planetary boundaries are not obviously compatible with traditional entity-focused management and accounting performance measures (Whiteman et al., 2013; Bebbington et al., 2014). To translate the concept to a sectoral level is equally complex, as we seek to illustrate in Figure 1.

Figure 1 is a heuristic that attempts to conceptualise how sustainability might translate from a global level to a sectoral level, specifically the agri-food sector in Ireland. The outer layer of Figure 1 is the global level, where we place the nine planetary boundaries. Steffen et al. (2015) stress that the model is not designed to be scaled down to nations and communities, but can 'inform and support global sustainability goals and pathways'. They suggest that it 'will need to be implemented alongside the achievement of targets aimed at more immediate human needs, such as provision of clean, affordable and accessible energy and the adequate supply of food'. Steffen et al. suggest the UN SDGs as a framework, which provides these targets, and the SDGs have been used to frame global and national policies in relation to sustainability. ${ }^{2}$ For example, each country that has signed up to the SDGs is required to periodically report its progress on each goal to the UN. For these reasons, we have situated the SDGs as the next level below planetary boundaries in Figure 1, spanning both the global and national layers of the diagram. The next layer that we identify is the sectoral level, in this case the Irish agri-food sector and the different types of organisations and products within it. However, we note a point of complication here; that sectors transcend national boundaries, and reporting at the level of global supply chains is complex (e.g. see Marshall et al., 2016). For example, a significant percentage of Irish agri-food output is exported for example 90 per cent of beef production in 2014 was exported (Teagasc, 2016).

To begin to conceptualise sector-level sustainability accounting and reporting, it is imperative to engage with sustainability at multiple levels. The layers of Figure 1 are tightly interconnected, for example the agri-food sector is responsible for 32 per cent of Ireland's GHG emissions (EPA, 2016), meaning that the activity of the sector, and each organisation within it, has a direct impact on Ireland's contribution to the SDGs, and on the integrity of planetary boundaries. This interconnectedness of systems has long been a key feature of the sustainability debate (e.g. Gladwin et al., 1995; Newton, 2002; Shrivastava and Kennelly, 2013). The question for scholars and practitioners becomes: how to begin to account for or report on sustainability in such a complex arena? 
A useful place to begin is to identify existing indicators and sustainability reporting frameworks at each of the levels identified in Figure 1, which we summarise in Figure 2. First, we consider the global level, at which the planetary boundaries are but one set of indicators of sustainability. Other prominent measures are the ecological footprint, developed by Wackernagel and Rees (1996), and, inter alia, the water footprint, carbon footprint, chemical footprint etc. (see Fang et al., 2015a, for a review). A number of scholars have attempted to apply these measures at a national level (Wackernagel et al., 1999; Fang et al., 2015b; Lammers et al., 2008). These studies offer frameworks of sorts for measuring the ecological impact of individual states, so Ireland's impact on planetary boundaries could be calculated, or Ireland's ecological footprint, as the Global Footprint Network (2016) demonstrates. This brings us a step closer to sector-level indicators.

\section{FIGURE 2: SUSTAINABILITY INDICATORS AND REPORTING FRAMEWORKS AT DIFFERENT LEVELS}

\begin{tabular}{|c|c|c|}
\hline $\begin{array}{l}\text { Global SD } \\
\text { indicators }\end{array}$ & \multicolumn{2}{|c|}{$\begin{array}{l}\text { - Planetary boundaries (Rockstrom et al., 2009; Steffen et al., 20I5) } \\
\text { - Sustainable Development Goals (UN, 20I5) } \\
\text { - Environmental footprints inc. water, ecological, carbon (Fang et al., 20 I5a) }\end{array}$} \\
\hline $\begin{array}{l}\text { National SD } \\
\text { indicators }\end{array}$ & \multicolumn{2}{|c|}{$\begin{array}{l}\text { - Ecological footprint (WWF, 20 I6; Lammers et al., 2008; Wackernagel et al., } \\
\text { I999) } \\
\text { - Environmental Economic Accounting (Obst, 20I5; Edens and Hein, 20I3; } \\
\text { UNFAO, 20 I6a) } \\
\text { - Planetary boundaries (Hayha et al., 20 I6; Fang et al., 20I5b) }\end{array}$} \\
\hline Sector-level & $\begin{array}{l}\text { - Natural Capital Protocol } \\
\text { (Natural Capital Coalition, 2016) } \\
\text { - OECD Agri-environmental } \\
\text { indicators (OECD, 20I3) }\end{array}$ & $\begin{array}{l}\text { - EU's Organisation Environmental } \\
\text { Footprint (EU, 20I2) } \\
\text { - System of Environmental Economic } \\
\text { Accounting (SEEA) (UNSD, 20I6) }\end{array}$ \\
\hline $\begin{array}{l}\text { Organisation- } \\
\text { level }\end{array}$ & $\begin{array}{l}\text { - Reporting standards } \\
\text { e.g. GRI, ISO26000, } \\
\text { UN Global Compact }\end{array}$ & $\begin{array}{l}\text { ing tools e.g. } \\
\text { sst Accounting (Bebbington et al., 200I) } \\
\text { lability Assessment Model } \\
\text { ngton et al., 2007) } \\
\text { nmental P\&L (Puma, 20I I) } \\
\text { lability indicators (Pretty et al., 2008) }\end{array}$ \\
\hline Product-level & \multicolumn{2}{|c|}{$\begin{array}{l}\text { - Life cycle assessment e.g. ISO I4044 } \\
\text { - Product Environmental Footprint (EU, 20I3) }\end{array}$} \\
\hline
\end{tabular}

There are also many frameworks and indicators of sustainability at the organisation and product levels. ISO14044 provides a framework for individual product lifecycle assessment, while the EU in 2016 completed the pilot phase of its Product Environmental Footprint project, covering 22 products from batteries to pet food. Such assessments are complex, as illustrated by Gray and Bebbington's (2001) attempt to complete a life cycle assessment for a pencil.

The organisational level provides a rich array of sustainability indicators, with reporting standards such as ISO26000, the Sustainability Accounting and Standards 
Board and, most prominently, the GRI Guidelines. These comprehensive guidelines are widely used, but have been extensively criticised (Fonesca et al., 2014; Milne and Gray, 2013; Marimon et al., 2012; Moneva et al., 2006). Furthermore, they do not as yet provide substantive guidance on multiple organisation reporting. Though thrice updated since their inception in 2000, the GRI guidelines remain largely limited to the organisational level. The only allusion towards industry or supply-chain level reporting is in the G4 Guidelines (the latest iteration), G4-EN4, which includes 'energy consumption outside of the organization'. This requires the organisation to identify relevant upstream or downstream energy consumption in activities or categories such as 'purchased goods and services' and 'use of sold products'. Organisations are not advised on how much detail to include in this disclosure.

Many scholars, particularly in the environmental accounting field, have done innovative work on accounting for sustainability at an organisational level (see Bebbington and Larrinaga, 2014, for a summary). In this category we place the work on full-cost accounting (Bebbington et al., 2001), sustainable cost calculation (Bebbington and Gray, 2001), sustainability gap analysis (Ekins et al., 2003), sustainable value-added (Figge and Hahn, 2004) and the environmental P\&L (Puma, 2011). However, these calculations typically struggle with accounting for impacts beyond the boundaries of the organisation (Gray, 2010). For example, Lamberton (2000, p. 601) attempts to develop an account of sustainability in a small organic farm, but concludes that 'the goal of ecological sustainability appears out of reach of individual business organisations at least in the medium term' because they 'operate within an ecologically unsustainable industrial system'. Lamberton (2000, p. 603) observes that businesses that prioritise ecological sustainability are 'forced to be competitive with organisations that do not consistently pursue ecological and social goals', an issue also discussed by Young and Tilley (2006). Sector-level sustainability reporting is an interesting prospect in this regard, as it would likely require shared goals between multiple organisations.

There is also an extensive literature on sustainable supply chain management (see Seuring and Muller, 2008 for a review) which engages with sustainability in multiple organisations. However, this work, as far as we are aware, has little engagement with the accounting and reporting literature. Furthermore, it focuses largely on how individual organisations can minimise risk in their supply chain and whether it 'pays to be green' (Pagell and Shevchenko, 2014), rather than measuring and reporting the environmental and social impacts of multiple organisations or the supply chain as a whole.

\section{TOWARDS SECTOR-LEVEL SUSTAINABILITY REPORTING IN THE AGRI-FOOD SECTOR?}

We now turn our attention to emerging guidelines for sector-level sustainability reporting, specifically in the agri-food sector. After the review process undertaken in 'Sustainability Indicators and Reporting Guidelines' section, four sources of sector-level sustainability indicators were identified, as detailed in Table 2. Each of these sources could potentially offer a framework for sector-level sustainability 


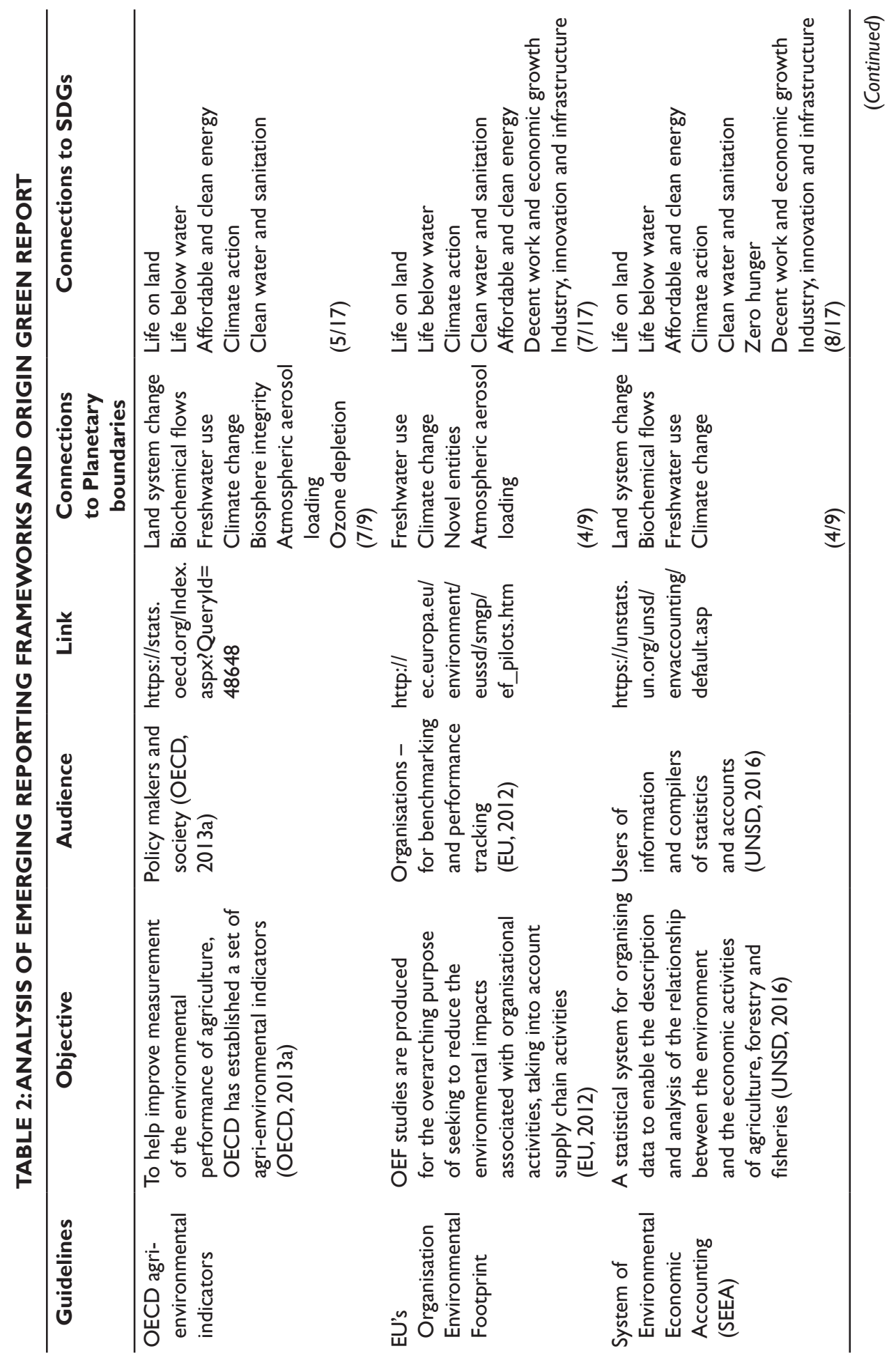




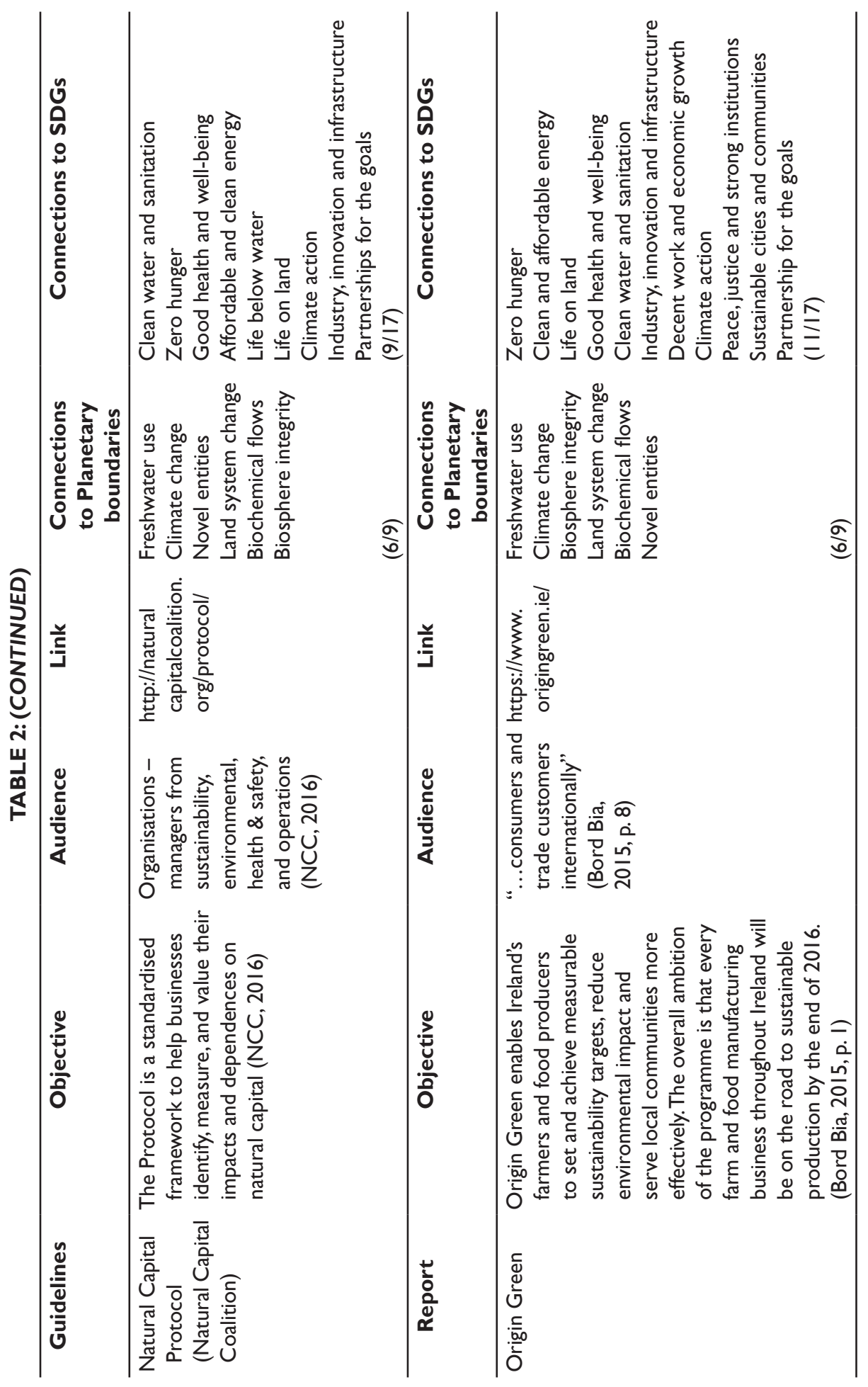


reporting. ${ }^{3}$ We review each of these four emerging frameworks below, which is summarised in Table 2. Reflecting the importance of considering sustainability at multiple levels, as illustrated in Figure 1, in our review we seek to identify linkages, if any, between these indicator sets and both Rockstrom et al.'s (2009) planetary boundaries and the UN SDGs. We also use this method to review Bord Bia's 2015 Origin Green report, a practitioner example of a sector-level sustainability report and our operational anchoring point for the study. A summary of the key characteristics of the four frameworks evaluated, plus the Origin Green report, including their connections to planetary boundaries and the SDGs, is illustrated in Table 2.

\section{OECD Agri-Environmental Indicators}

The OECD agri-environmental indicators (OECD, 2013a) offer a comprehensive framework for reporting environmental impacts at farm level, incorporating 98 indicators in 15 categories, including agricultural land use, nutrients, pesticides, GHG emissions and water quality. The latest report, published in 2013, provides data on a selection of these indicators for the Irish agri-food industry from 1990 to 2010. Data are drawn from Eurostat and FAO, the Food and Agriculture Organisation of the United Nations. The OECD has published a number of reports on environmental indicators, but the agri-environmental indicators report appears to be the only one that reports on a specific sector. The only other potentially relevant report for sector-level reporting is one that calculates waste per sector in the agriculture, energy, mining and construction sectors (OECD, 2017).

The OECD agri-environmental indicators engage at some level with seven of the nine planetary boundaries, making this framework, of those we analysed, the one that relates most directly to the planetary boundaries concept. For example, Land System Change is addressed by various indicators relating to agricultural land use, such as 'share of agricultural land area in the national land area', while Biochemical Flows is addressed by a number of indicators relating to nitrogen and phosphorus balance. There are also several indicators related to Climate Change and Freshwater Use, but only one, 'farmland bird index', measuring biosphere integrity. The framework is less closely aligned to the SDGs, matching only to the goals that address environmental aspects of development, such as Life on Land, Life below Water and Climate Action. Some of the SDGs that we might expect the framework to address are those related to the agri-food system such as Zero Hunger and Good Health and Well-Being, but these do not appear to be engaged with.

\section{EU Organisation Environmental Footprint}

The EU's Organisation Environmental Footprint is an ongoing project, which forms part of the EU's work on Sustainable Consumption and Production, which emphasises a sectoral approach to sustainability. The pilot phase of the project, which also looked at Product Environmental Footprint for products as diverse as IT equipment, footwear and dairy, was completed between 2013 and 2016 and covered two sectors - Retail and Copper Production.

The EU's draft guidelines for measuring Organisation Environmental Footprint in the Retail sector define 'system boundaries' that extend beyond the typical 
single-entity boundary. The EU suggests that the organisation 'shall' take account of its upstream (supplier) activities and 'should' take account of downstream (customer) activities. The EU has provided an Excel spreadsheet designed for data collection in relation to 137 indicators across the retailer's factories, retail places, distributors and support services. These indicators range from the expansive ('number of employees at each site') to the minute ('are vegetarian meals suggested in the employee canteen?'). They also cover some important impacts on the processing, retail and transport stages of the supply chain, such as 'refrigerant gasses - annual loss' or 'fraction of consumer coming by car'.

Our review indicates that the EU OEF framework engages with four planetary boundaries. It is particularly focused on toxic chemicals and pollutants, including measures for refrigerant gases, hazardous wastes and GHG emissions. It also refers to Novel Entities, looking at 'plastic recycling' and 'repacking plastic consumption', which the OECD agri-environmental indicators do not. Like the OECD indicators, the EU OEF engages largely with the environmentally focused SDGS, although it does additionally address Decent Work and Economic Growth and Industry, Innovation and Infrastructure to an extent through indicators such as 'number of full-time employees'.

\section{System of Environmental Economic Accounting}

The System of Environmental Economic Accounting (SEEA) is an ongoing project by the United Nations Statistics Division (UNSD). It is based on the premise of national environmental economic accounts, which calculate a country's stocks and changes in environmental assets. The primary focus of the project is on water and energy, but the UNSD also published a consultation document in 2016 related to SEAA for Agriculture, Forestry and Fisheries. Two types of accounts are proposed, asset and physical flow accounts, for resources such as water, energy and land and groups of agricultural assets for example livestock and crops. Sector-level reports are drawn from the accounts to show economic and environmental variables such as production quantity and GHG emissions respectively.

As Table 2 illustrates, the SEEA engages with four planetary boundaries. Like the OECD agri-environmental indicators, Land System Change is measured by 'Agricultural land area', and phosphorus and nitrogen balance are also measured. In relation to Freshwater Use, the SEAA asks for data on 'total agricultural water withdrawals', as does the OECD. Looking at the SDGs, a feature of the SEAA is that it engages to an extent with Zero Hunger by measuring 'Total food purchased/ obtained by households' and 'kcal per capita per day'. Apart from this, it is again the environmental SDGs that are addressed for example Life on Land, Life below Water, Affordable and Clean Energy.

\section{Natural Capital Protocol}

The Natural Capital Coalition (NCC) is an international collaboration between almost 250 organisations, including business, academia, NGOs, policy-makers and standard setters, including the Institute of Chartered Accountants in England and Wales (ICAEW) and the GRI. The NCC was created with the aim of integrating natural capital into business decision-making. Natural capital refers to the 'stocks' of 
natural resources for example water, air, plants, soil, on which business impacts or is dependent on.

The NCC has developed the Natural Capital Protocol, a framework intended to be 'complementary' with other frameworks like the SDGs and GRI Guidelines, which allows the organisation to integrate natural capital into business decisionmaking. The Protocol asks organisations to 'identify, measure and value their impacts and dependencies on natural capital' (Natural Capital Coalition, 2017).

The scope of the Natural Capital Protocol covers the full life-cycle of a product, with organisations asked to account for upstream, direct operations and downstream activities, including purchase, use and disposal of products. In this way, the Protocol offers a potential framework for accounting for sustainability at a sectoral level. NCC has also created detailed sector guidance for the Food \& Beverage and Apparel sectors, including practical examples of risks and opportunities across the $P \& L$, and they welcome any organisations interested in developing further sectorspecific guides.

The Protocol lists specific 'impact drivers' (Natural Capital Coalition, 2016, p. 43), which we have used to analyse its engagement with planetary boundaries and the SDGs. Looking at Land System Change and Freshwater Use, the Protocol asks organisations to calculate figures such as 'Area of agriculture by type, area of forest plantation by type, area of open cast mine by type, etc' and 'Area of wetland, ponds, lakes, streams, rivers or peatland necessary to provide ecosystem services'. It also looks at the 'volume of waste by classification' (Novel Entities) and 'Crop pest control, pollination' (Biosphere Integrity). In relation to the SDGs, we posit that the Natural Capital Protocol engages at a basic level with the SDG of Zero Hunger by including the measure 'Human or animal food' and with Good Health and Well-Being through 'Employee satisfaction and stress release, sacred sites and indigenous traditions that support company staff or operations'.

\section{Emerging Reporting: Origin Green}

To the best of our knowledge, Bord Bia's Origin Green programme represents a unique attempt to account for sustainability at a sectoral level. Launched in 2012 the programme is a 'national sustainability programme for the Irish food and drink industry' (Bord Bia, 2015). The stated aim of the programme is to lower the industry's carbon footprint, and it requires Bord Bia to form partnerships with farmers and food and drink companies. In the 2016 report, data are presented from 62,000 farms and 220 member companies. As such it serves as an example of multiple organisational reporting in the environmentally significant agri-food sector and the operational anchoring point for our study.

The first Origin Green report, a 113-page account of farm assessment and company targets, was produced in 2015. Figures are presented in the report for energy use, emissions, water use and waste in member companies, both per unit of output and in absolute terms. Although the report does not attempt to comprehensively calculate what Gray and Milne (2002) refer to as the 'cumulative effect' of organisational activity on the 'carrying capacity of given ecosystems', there is some evidence that Bord Bia is seeking to engage with reporting on the cumulative effect of the agri-food industry. In the 2015 report they report on the farm and processing stages 
of the supply chain, and within that average emissions per kilo (as opposed to total emissions) are calculated for two product categories, beef and dairy, while in the 2016 report they expand to the retail and food service stage, engaging with Musgraves (a large Irish-based retailer) and McDonalds. This suggests that to comprehensively account and report for sustainability across all stages of the supply chain might be a very challenging aim for practitioners, requiring both substantive engagement across the sector and a commitment and ability to report quantitatively in this way.

The engagement of the 2015 and 2016 Origin Green reports with the planetary boundaries and SDGs was also analysed. The 2015 Report engages to an extent with six of the nine planetary boundaries, with Freshwater Use, Climate Change and Biosphere Integrity (in the form of biodiversity) measured in relation to both farms and companies. Novel Entities are addressed by setting waste and packaging reduction targets for companies. Biochemical Flows are only engaged within a small section written by the EPA, where nitrogen and phosphorus levels in water are briefly mentioned. Land System Change is addressed in the form of efforts to encourage forestry planting on farmland, but the percentage of land used for agriculture, present in both the OECD agri-Environmental indicators and the Natural Capital Protocol, is not measured. The 2016 report engages with the same planetary boundaries, largely to the same extent. However, this report does not refer to forestry and although water quality is discussed, nitrogen and phosphorus are not specifically mentioned.

Our analysis suggests that the 2015 Origin Green report engages to some extent with 11 of the 17 SDGs, indicating awareness of global development issues. This means that the Origin Green framework is ostensibly more engaged with the SDGs than the emerging guidelines we reviewed. This is largely because the Origin Green reports engage implicitly with aspects of social sustainability, such as Decent Work and Economic Growth, Sustainable Cities and Communities, and Good Health and Well-Being, through the Social Sustainability targets for member companies. The 2015 report also engages in an implicit way with the goal of Zero Hunger by referring to 'meeting the ever-increasing demand for food' (Bord Bia, 2015, p. 3). The 2016 report engages explicitly with the SDGs, with Bord Bia suggesting that Origin Green aligns with nine of the goals: Good Health and Well-Being, Clean Water and Sanitation, Affordable and Clean Energy, Sustainable Communities, Responsible Consumption \& Production, Climate Action, Life Below Water, Life on Land and Partnership. The report states that they identified relevant goals by assessing 'where the industry has impact on a goal.... or where it can contribute to the actual achievement of a goal'. However, the report does not discuss whether the industry has a positive or negative impact on a goal and does not consider the potential tensions between the ambitious growth targets for the industry consistent with the Irish government's FoodHarvest2020, and the SDG of Responsible Consumption and Production. 


\section{DISCUSSION}

The literature review revealed few existing studies on multiple organisation sustainability reporting, none of which have looked at sector-level sustainability reporting. This paper has sought to offer a first-focused mapping of the terrain of sector-level sustainability reporting, to review the existing literature and emerging reporting guidelines, and provide guidance to researchers and practitioners seeking to engage with this area.

Our analysis of emerging guidelines, summarised in Table 2, suggests that there are several projects in progress that take different approaches, both in method and content, to accounting for sustainability at the level of multiple organisations. We saw that institutions such as the EU, the OECD and the UN are all developing multiple organisation sustainability reporting frameworks, although there are no cohesive guidelines in place as yet. This raises issues as to how practitioners will or will not engage with the work of these institutions when reporting, for example Bord Bia has chosen to date not to engage with these emerging guidelines in their 2015 and 2016 Origin Green reports. Some guidelines, such as the OECD agrienvironmental indicators, relate more to the planetary boundaries concept and some, such as the Natural Capital Protocol, to the SDGs. None of the guidelines we reviewed address all elements of either of these high-level frameworks, indicating a lack of consideration of broader sustainability parameters in the development of the guidelines. The Origin Green report is the only emerging reporting framework we identified that explicitly references the SDGs. It appears that there is a disconnection between global sustainability parameters, emerging guidelines and practitioner reporting.

Mapping the terrain of sector-level sustainability reporting and identifying the linkages, between global parameters of sustainable development, emerging guidelines for sector-level sustainability reporting and emerging reporting in the form of Bord Bia's Origin Green program, provides insight into the potential of sectorlevel reporting to advance the field of sustainability reporting. It is suggested that multiple organisation reporting can contribute to the development of substantive sustainability reporting, helping to quantify the ecological impact of particular industries, supply chains or clusters of organisations and ultimately measuring the impact of business activity on planetary boundaries. However, it is not clear that measuring and reporting on the sustainability frameworks and indicators for the agri-food sector emerging from the EU, OECD, UN and others will necessarily bring us closer to sustainability. While the guidelines identified and the Origin Green report engage with aspects of global frameworks, they do not attempt to report on the cumulative effect of activity on ecological carrying capacity. For example, the 2015 and 2016 Origin Green reports suggest that Bord Bia has engaged with actors at various stages of the supply chain, but even with this scale of engagement, the reporting is still incomplete; Origin Green does not yet report the cumulative effect of activity in the sector. This highlights the significant challenge of reporting on sustainability at a sectoral or multiple organisation level.

Furthermore, the guidelines at the moment are diverse, incomplete, and also potentially onerous. For example, if an organisation was to report on every indicator 
in the four emerging guidelines we analysed, they would be reporting on at least 200 indicators. This raises questions as to the ability of practitioners to navigate these guidelines. To gather data to populate frameworks such as the UN SEEA would be a significant task, requiring co-ordination with every farm, manufacturer, retailer, food service organisation, arguably every consumer in the supply chain. With its Origin Green programme Bord Bia has engaged with many of these actors, but its report does not offer any cumulative assessment of the ecological impact of the sector. This highlights the challenge of multiple organisation reporting, which could be affected by a number of factors. The literature (i.e. Russell and Thomson, 2009; Spence and Rinaldi, 2010, 2014) tells us that power relations between different actors in the supply chain may be important and in the case of Origin Green, there may be issues such as trust, commercial sensitivity, the need to protect members from adverse publicity, or the fact that members may not be progressing. There is also the broader issue of gaps in scientific knowledge for example some of the planetary boundaries are not defined.

In addition, to whom should the responsibility of compiling a sector-level sustainability report fall? In the case of the agri-food industry in Ireland, a semi-state body, Bord Bia, has taken on that responsibility, but it is unlikely that every industry would have an equivalent body with the motivation and resources to complete such a complicated exercise. Our review suggests that sector-level sustainability reporting will require negotiation between organisations on what should and/or can be reported, by whom and for whom. This is likely to be a major challenge for practitioners and regulators. For example, in piloting its Organisation Environmental Footprint project, the EU initially selected three sectors of study, but was forced to abandon its study of the Household Sanitary Goods and Toiletries industry when it 'became progressively evident that the pilot was not sufficiently backed by the major producers and the relevant European associations' (EU, 2017). The EU notes that the pilot was cancelled because 'the Commission position about this exercise has always been not to impose anything to industry but rather to help addressing needs on their side' (EU, 2017). Single-entity reporting on social and environmental impacts has hitherto been voluntary - the GRI Guidelines are guidelines rather than regulations - but from FY2017 the EU Non-Financial Reporting Directive requires mandatory non-financial disclosure by certain organisation for the first time. We do not know how major producers and industry associations would react to mandatory multiple organisation sustainability reporting.

There is, however, the potential for substantive reporting of important data, which could not be accessed from single-entity reporting, from some of the emerging guidelines we have reviewed. For example, the OECD's agri-environmental indicators give us data on on-farm energy consumption (273,000 tonnes oil equivalent in 2010), pesticide sales (2,638 tonnes of active ingredients in 2010) and nitrogen balance $(213,724$ tonnes in 2009) in Ireland. These are substantive figures that give us some insight into how the Irish agri-food industry and the organisations within it are impacting planetary boundaries. Research is required to develop frameworks that can account for sector-level data such as this and allow scholars to influence policy and practice on substantive multiple organisation sustainability reporting. 


\section{CONCLUDING REMARKS}

It is increasingly acknowledged that to substantively report on sustainability, accounting scholars must consider the cumulative impact of multiple organisations on ecological systems (Gray and Milne, 2002; Bebbington and Larrinaga, 2014). Sustainability reporting at the industry, supply chain or sectoral level could allow us to calculate the impact of an industry on global sustainability parameters like planetary boundaries or the UN SDGs, and seek to reduce that impact. Guidelines for multiple organisation reporting are beginning to emerge and we also see a practitioner reporting example in the form of Bord Bia's Origin Green program. However, our analysis showed that both these emerging guidelines and the Origin Green report are largely disconnected from global parameters of sustainability, and do not provide a 'collective and cumulative assessment of economic activity relative to a resource base'. Our study indicates that sector-level reporting has the potential to advance the field of sustainability reporting, but is not as yet connected to key parameters of global sustainability.

As such the study raises several questions for future research. Firstly, how will organisations manage multiple organisation sustainability reporting? We do not yet know how sector-level, supply chain and industry-level sustainability reporting will manifest in practice. Empirical research is needed on practical issues - what systems, expertise and resources will be required; who in the organisation will manage the process and who the audience for such reports might be. Secondly, how will organisations negotiate reporting at the level of multiple organisations? Our insights, along with those of Spence and Rinaldi $(2014,2010)$, Georgakopolous and Thomson (2008) and Russell and Thomson (2009), suggest that power differentials will have a significant impact on how multiple organisation sustainability accounting is approached and implemented. Further research, using methods, such as interviews, case studies and ethnography, is required to understand how organisations will negotiate reporting at a sectoral level. Thirdly, what role will legislation play and is regulation appropriate or possible? Our review of emerging frameworks for sector-level sustainability reporting suggests that a number of international institutions are engaging with the concept of sustainability accounting and reporting at the level of multiple organisations. Some of these organisations, such as the EU, are potential regulators. Further research is required to assess the potential for and implications of related legislation for practitioners.

In addition, how can scholars seek to influence policy in this area? As this paper has illustrated, there are no existing cohesive guidelines for multiple organisation sustainability reporting. There is an opportunity for scholars to develop frameworks that can drive best practice in sustainability reporting at sector and supply chain levels. Furthermore, can single-entity reporting guidelines be extended to incorporate multiple organisations? As highlighted in Figure 1, sector-level sustainability reporting is far more complex than single-entity reporting. However, singleentity reporting is well-established and, as Figure 2 illustrates, there are several guiding frameworks for sustainability reporting at this level, along with an emerging regulatory framework in the form of the EU's new Non-financial Reporting 
Directive. Further research could explore the possibilities of extending these guidelines to a multiple organisation level.

This study has provided an initial mapping of the terrain of multiple organisation sustainability reporting. Our analysis leads us to conclude that it is imperative that management and accounting scholars engage with these issues and ultimately work to understand how 'accounting can contribute to a more sustainable/less unsustainable society' (Bebbington and Larrinaga, 2014, p. 410).

\section{ACKNOWLEDGEMENTS}

This study benefitted from the financial support of the the Chartered Accountants Ireland Educational Trust. The authors would also like to thank participants at the 2016 Irish Accounting and Finance Association Conference, the 2016 Centre for Social and Environmental Accounting (CSEAR) conference Ireland, the 2017 Centre for Not-for-profit and Public-sector Research (CNPR) Conference, the ENVIRON 2017 conference and the 2017 European Accounting Association conference, along with the two anonymous reviewers, for their constructive comments.

\section{ENDNOTES}

1 While conscious that Bebbington and Larrinaga (2014) refer to 'accounting for sustainable development', we use the term 'sustainability accounting and reporting' in the paper as consistent with the language used in the documentary data we collected.

2 Holden et al. (2017) argue that the SDGs do not reflect planetary boundaries, but are based on the 'triple bottom line' concept, where sustainability has three elements, social-environmental-economic, which has been widely criticised by sustainability accounting researchers (e.g. Henriques et al., 2004). Although we recognise this critique of the SDGs, we note that Steffen et al. (2015) suggest that the SDGs can be used alongside planetary boundaries to set development targets.

3 It is noted that the indicators identified are largely environmental; it appears that there is little data required by institutions such as the EU and OECD on social sustainability at a sector level.

\section{REFERENCES}

Aras, G. and Crowther, D. (2009). Corporate Sustainability Reporting: A Study in Disingenuity?, Journal of Business Ethics, Vol. 87, No. 1, pp. 279-288.

Bansal, P. and Song, H.C. (2017). Similar but not the same: Differentiating Corporate Responsibility from Sustainability, Academy of Management Annals, Vol. 11, No. 1, pp. 105-149.

Bebbington, J. (2007). Accounting for Sustainable Development Performance, Oxford: CIMA.

Bebbington, J. and Gray, R. (2001). An Account of Sustainability: Failure, Success and a Reconceptualization, Critical Perspectives on Accounting, Vol. 12, No. 5, pp. 557-587.

Bebbington, J. and Larrinaga, C. (2014). Accounting and Sustainable Development: An Exploration, Accounting, Organizations and Society, Vol. 39, No. 6, pp. 395-413.

Bebbington, J., Brown, J. and Frame, B. (2007). Accounting Technologies and Sustainability Assessment Models, Ecological Economics, Vol. 61, No. 2, pp. 224-236.

Bebbington, J., Gray, R., Hibbitt, C. and Kirk, E. (2001). Full Cost Accounting: An Agenda for Action. ACCA Research Report. London: ACCA. 
Bebbington, J., Unerman, J. and O'Dwyer, B. (2014). Sustainability Accounting and Accountability. Abingdon: Routledge.

Bjørn, A., Margni, M., Roy, P.O., Bulle, C. and Hauschild, M.Z. (2016). A Proposal to Measure Absolute Environmental Sustainability in Life Cycle Assessment, Ecological Indicators, Vol. 63, pp. 1-13.

Bord Bia (2015). Sustainability Report 2015. Dublin: Bord Bia.

Burritt, R.L. and Schaltegger, S. (2010). Sustainability Accounting and Reporting: Fad or Trend?, Accounting, Auditing \& Accountability Journal, Vol. 23, No. 7, pp. 829-846.

Careers Portal (2017). 'Agriculture, Horticulture, Forestry \& Food', available from: <http:// www.careersportal.ie/sectors/sectors.php?sector_id=2\#.WK2e1vKS8Ys>, accessed 22 February 2017.

Cho, C.H., Laine, M., Roberts, R.W. and Rodrigue, M. (2015). Organized Hypocrisy, Organizational Façades, and Sustainability Reporting, Accounting, Organizations and Society, Vol. 40, No. 1, pp. 78-94.

Deegan, C., Rankin, M. and Tobin, J. (2002). An Examination of the Corporate Social and Environmental Disclosures of BHP from 1983-1997: A Test of Legitimacy Theory, Accounting, Auditing \& Accountability Journal, Vol. 15, No. 3, pp. 312-343.

Dyllick, T. and Muff, K. (2016). Clarifying the Meaning of Sustainable Business: Introducing a Typology from Business-as-usual to True Business Sustainability, Organization E Environment, Vol. 29, No. 2, pp. 156-174.

Edens, B. and Hein, L. (2013). Towards a Consistent Approach for Ecosystem Accounting, Ecological Economics, Vol. 90, pp. 41-52.

Ekins, P., Simon, S., Deutsch, L., Folke, C. and De Groot, R. (2003). A Framework for the Practical Application of the Concepts of Critical Natural Capital and Strong Sustainability, Ecological Economics, Vol. 44, No. 2, pp. 165-185.

Environmental Pillar (2016). Not so Green: Debunking the Myths around Irish Agriculture. Boyle: Environmental Pillar.

EPA (Environmental Protection Agency) (2009). Food Waste Prevention and Home Composting Report. Dublin: Environmental Protection Agency.

EPA (Environmental Protection Agency) (2016). Ireland's Environment an Assessment 2016. Johnstown Castle: Environmental Protection Agency.

EU (2008). Sustainable Consumption and Production and Sustainable Industrial Policy Action Plan - Council Conclusions. Brussels: Council of the European Union.

EU (2016). OEF Retail Data Collection Template, available from: <https://webgate.ec.europa. eu/fpfis/wikis/display/EUENVFP/Stakeholder+workspace\%3A+OEFSR+pilot+Ret ail $>$, accessed 5 December 2016 [Registration Required].

EU (2017). The Environmental Footprint Pilots, available from: <http://ec.europa.eu/ environment/eussd/smgp/ef_pilots.htm>, accessed 7 February 2017.

Fang, K., Heijungs, R. and De Snoo, G.R. (2015a). Understanding the Complementary Linkages Between Environmental Footprints and Planetary Boundaries in a Footprintboundary Environmental Sustainability Assessment Framework, Ecological Economics, Vol. 114, pp. 18-226.

Fang, K., Heijungs, R., Duan, Z. and de Snoo, G.R. (2015b). The Environmental Sustainability of Nations: Benchmarking the Carbon, Water and Land Footprints Against Allocated Planetary Boundaries, Sustainability, Vol. 7, No. 8, pp. 11285-11305.

Fifka, M.S. (2013). Corporate Responsibility Reporting and Its Determinants in Comparative Perspective - A Review of the Empirical Literature and a Meta-Analysis, Business Strategy and the Environment, Vol. 22, No. 1, pp. 1-35.

Figge, F. and Hahn, T. (2004). Sustainable Value Added - Measuring Corporate Contributions to Sustainability Beyond Eco-Efficiency, Ecological Economics, Vol. 48, No. 2, pp. 173-187. 
Fonseca, A., McAllister, M.L. and Fitzpatrick, P. (2014). Sustainability Reporting Among Mining Corporations: A Constructive Critique of the GRI Approach, Journal of Cleaner Production, Vol. 84, No. 1, pp. 70-83.

Georgakopoulos, G. and Thomson, I. (2008). Social Reporting, Engagements, Controversies and Conflict in an Arena Context, Accounting, Auditing \& Accountability Journal, Vol. 21, No. 8, pp. 1116-1143.

Gladwin, T.N., Kennelly, J.J. and Krause, T.S. (1995). Shifting Paradigms for Sustainable Development: Implications for Management Theory and Research, Academy of Management Review, Vol. 20, No. 4, pp. 874-907.

Global Reporting Initiative (2017). G4-EN4 Energy Consumption Outside of the Organisation, available from: <https://g4.globalreporting.org/specific-standard-disclosures/ environmental/energy/Pages/G4-EN4.aspx>, accessed 23 February 2017.

Gray, R. (2006). Social, Environmental and Sustainability Reporting and Organisational Value Creation? Whose Value? Whose Creation?, Accounting, Auditing \& Accountability Journal, Vol. 19, No. 6, pp. 793-819.

Gray, R. (2010). Is Accounting for Sustainability Actually Accounting for Sustainability... and How Would We Know? An Exploration of Narratives of Organisations and the Planet, Accounting, Organizations and Society, Vol. 35, No. 1, pp. 47-62.

Gray, R. and Bebbington, J. (2001). Accounting for the Environment, London: Sage.

Gray, R. and Milne, M. (2002). Sustainability Reporting: Who's Kidding Whom?, Chartered Accountants Journal of New Zealand, Vol. 81, No. 6, pp. 66-70.

Gray, R., Dey, C., Owen, D., Evans, R. and Zadek, S. (1997). Struggling with the Praxis of Social Accounting: Stakeholders, Accountability, Audits and Procedures, Accounting, Auditing \& Accountability Journal, Vol. 10, No. 3, pp. 325-364.

Guthrie, J. and Abeysekera, I. (2006). Content Analysis of Social, Environmental Reporting: What Is New?, Journal of Human Resource Costing \& Accounting, Vol. 10, No. 2, pp. 114-126.

Häyhä, T., Lucas, P.L., van Vuuren, D.P., Cornell, S.E. and Hoff, H. (2016). From Planetary Boundaries to National Fair Shares of the Global Safe Operating Space - How Can the Scales Be Bridged?, Global Environmental Change, Vol. 40, pp. 60-72.

Henriques, A. and Richardson, J. (eds) (2004). The Triple Bottom Line: Does It All Add Up?, Abingdon: Routledge.

Herbohn, K. (2005). A Full Cost Environmental Accounting Experiment, Accounting, Organizations and Society, Vol. 30, No. 6, pp. 519-536.

Hess, T.M., Chatterton, J. and Williams, A. (2012). The Water Footprint of Irish Meat and Dairy Products, Cranfield University.

Hoekstra, A.Y. and Wiedmann, T.O. (2014). Humanity's Unsustainable Environmental Footprint, Science, Vol. 344, No. 6188, pp. 1114-1117.

Hoffman, A.J. and Jennings, P.D. (2015). Institutional Theory and the Natural Environment: Research in (and on) the Anthropocene, Organization \& Environment, Vol. 28, No. 1, pp. 8-31.

Holden, E., Linnerud, K. and Banister, D. (2017). The Imperatives of Sustainable Development, Sustainable Development, Vol. 25, No. 3, pp. 213-226.

KPMG (2015). KPMG Survey of Corporate Responsibility Reporting, The Netherlands: KPMG International.

Laine, M. (2010). Towards Sustaining the Status Quo: Business Talk of Sustainability in Finnish Corporate Disclosures 1987-2005, European Accounting Review, Vol. 19, No. 2, pp. 247-274.

Lamberton, G. (2000). Accounting for Sustainable Development - A Case Study of City Farm, Critical Perspectives on Accounting, Vol. 11, No. 5, pp. 583-605.

Lammers, A., Moles, R., Walsh, C. and Huijbregts, M.A. (2008). Ireland's Footprint: A Time Series for 1983-2001, Land Use Policy, Vol. 15, No. 1, pp. 53-58. 
Mäkelä, H. and Laine, M. (2011). A CEO with Many Messages: Comparing the Ideological Representations Provided by Different Corporate Reports, Accounting Forum, Vol. 35, No. 4, pp. 217-231.

Marimon, F., del Mar Alonso-Almeida, M., del Pilar Rodríguez, M. and Alejandro, K.A.C. (2012). The Worldwide Diffusion of the Global Reporting Initiative: What is the Point?, Journal of Cleaneran Production, Vol. 33, pp. 132-144.

Medawar, C. (1976). The Social Audit: A Political View. Accounting, Organizations and Society, Vol. 1, No. 4, pp. 389-394.

Milne, M.J. and Gray, R. (2013). W(h)ither Ecology? The Triple Bottom Line, the Global Reporting Initiative, and Corporate Sustainability Reporting, Journal of Business Ethics, Vol. 118, No. 1, pp. 13-29.

Milne, M.J. and Patten, D.M. (2002). Securing Organizational Legitimacy: An Experimental Decision Case Examining the Impact of Environmental Disclosures, Accounting, Auditing E Accountability Journal, Vol. 1593, pp. 372-405.

Milne, M.J., Tregidga, H. and Walton, S. (2009). Words Not Actions! The Ideological Role of Sustainable Development Reporting, Accounting, Auditing \& Accountability Journal, Vol. 22, No. 8, pp. 1211-1257.

Milne, M.J., Kearins, K.N. and Walton, S. (2006). Creating Adventures in Wonderland: The Journey Metaphor and Environmental Sustainability, Organization, Vol. 13, No. 6, pp. 801-839.

Moneva, J.M., Archel, P. and Correa, C. (2006). GRI and the Camouflaging of Corporate Unsustainability, Accounting Forum, Vol. 30, No. 2, pp. 121-137.

Montiel, I. and Delgado-Ceballos, J. (2014). Defining and Measuring Corporate Sustainability: Are We There Yet?, Organization \& Environment, Vol. 27, No. 2, pp. 113-139.

Natural Capital Coalition (2016). Natural Capital Protocol: Food and Beverage Sector Guide. Natural Capital Coalition, available from: <http://naturalcapitalcoalition.org/wp-content/ uploads/2016/07/NCC_FoodAndBeverage_WEB_2016-07-12.pdf $>$, accessed 6 December 2016.

Newton, T.J. (2002). Creating the New Ecological Order? Elias and Actor-network Theory, Academy of Management Review, Vol. 27, No. 4, pp. 523-540.

O'Dwyer, B. (2002). Managerial Perceptions of Corporate Social Disclosure: An Irish Story, Accounting, Auditing \& Accountability Journal, Vol. 15, No. 3, pp. 406-436.

Obst, C.G. (2015). Reflections on Natural Capital Accounting at the National Level: Advances in the System of Environmental-Economic Accounting, Sustainability Accounting, Management and Policy Journal, Vol. 6, No. 3, pp. 315-339.

OECD (2013a). 2013 Edition of the OECD Environmental Database: Data for Ireland, available from: <http://stats.oecd.org/Index.aspx?QueryId=48648>, accessed 7 December 2016.

OECD (2013b). Food Waste, available from: <https://stats.oecd.org/Index.aspx?DataSet Code=FOOD_WASTE $>$, accessed 7 December 2016.

OECD (2017). Generation of Waste by Sector, available from: <https://stats.oecd.org/Index. aspx?DataSetCode=WSECTOR>, accessed 24 February 2017.

Pagell, M. and Shevchenko, A. (2014). Why Research in Sustainable Supply Chain Management Should Have No Future, Journal of Supply Chain Management, Vol. 50, No. 1, pp. 44-55.

Parker, L.D. (2005). Social and Environmental Accountability Research: A View from the Commentary Box, Accounting, Auditing \& Accountability Journal, Vol. 18, No. 6, pp. 842-860.

Pretty, J., Smith, G., Goulding, K.W.T., Groves, S.J., Henderson, I., Hine, R.E., King, V., Van Oostrum, J., Pendlington, D.J., Vis, J.K. and Walter, C. (2008). Multi-Year Assessment of Unilever's Progress towards Agricultural Sustainability: Indicators, Methodology and Pilot Farm Results, International Journal of Agricultural Sustainability, Vol. 6, No. 1, pp.37-62. 
PUMA (2011). PUMA's Environmental Profit and Loss Account for the year ended 31 December 2010, available from: <http://about.puma.com/damfiles/default/sustainability/ environment/e-p-1/EPL080212final-3cdfc1bdca0821c6ec1cf4b89935bb5f.pdf>, accessed 23 February 2017.

Rinaldi, L., Unerman, J. and Tilt, C. (2014). The Role of Stakeholder Engagement and Dialogue within the Sustainability Accounting and Reporting Process, in J. Bebbington, J. Unerman and B. O'Dwyer (eds) Sustainability Accounting and Accountability. Abingdon: Routledge, pp. 86-117.

Rockström, J., Steffen, W., Noone, K., Persson, Å., Chapin, F.S., Lambin, E.F., Lenton, T.M., Scheffer, M., Folke, C., Schellnhuber, H.J. and Nykvist, B. (2009). A Safe Operating Space for Humanity, Nature, Vol. 461, No. 7263, pp. 472-475.

Russell, S.L. and Thomson, I. (2009). Analysing the Role of Sustainable Development Indicators in Accounting for and Constructing a Sustainable Scotland, Accounting Forum, Vol. 33, No. 3, pp. 225-244.

Schaltegger, S. and Burritt, R.L. (2010). Sustainability Accounting for Companies: Catchphrase or Decision Support for Business Leaders?, Journal of World Business, Vol. 45, No. 4, pp. 375-384.

Seuring, S. and Müller, M. (2008). From a Literature Review to a Conceptual Framework for Sustainable Supply Chain Management, Journal of Cleaner Production, Vol. 16, No. 15, pp. 1699-1710.

Shrivastava, P. and Kennelly, J.J. (2013). Sustainability and Place-Based Enterprise, Organization \& Environment, Vol. 26, No. 1, pp. 83-101.

Spence, C. (2007). Social and Environmental Reporting and Hegemonic Discourse, Accounting, Auditing \& Accountability Journal, Vol. 20, No. 6, pp. 855-882.

Spence, L.J. and Rinaldi, L. (2014). Governmentality in Accounting and Accountability: A Case Study of Embedding Sustainability in a Supply Chain, Accounting, Organizations and Society, Vol. 39, No. 6, pp. 433-452.

Spence, L.J. and Rinaldi, L. (2010). Sainsbury's: Embedding Sustainability within the Supermarket Supply Chain, in A. Hopwood, J. Unerman and J. Fries (eds), Accounting for Sustainability: Practical Insights, London: Earthscan, pp. 48-71.

Steffen, W., Richardson, K., Rockström, J., Cornell, S.E., Fetzer, I., Bennett, E.M., Biggs, R., Carpenter, S.R., de Vries, W., de Wit, C.A. and Folke, C. (2015). Planetary Boundaries: Guiding Human Development on a Changing Planet, Science, Vol. 347, No. 6223, p. 1259855.

Thomson, I. (2014). Mapping the Terrain of Sustainability and Accounting for Sustainability, in J. Bebbington, J. Unerman and B. O'Dwyer (eds), Sustainability Accounting and Accountability. Abingdon: Routledge, pp. 38-51.

Tregidga, H., Milne, M. and Kearins, K. (2014). (Re) Presenting 'Sustainable Organizations', Accounting, Organizations and Society, Vol. 39, No. 6, pp. 477-494.

Ullmann, A.A. (1976). The Corporate Environmental Accounting System: A Management Tool for Fighting Environmental Degradation, Accounting, Organizations and Society, Vol. 1, No. 1, pp. 71-79.

UNDP (United Nations Development Programme) (2015). Human Development Report 2015, New York: UNDP.

UNEP (United Nations Environment Programme) (2016). The Emissions Gap Report 2016, Nairobi: UNEP.

UNFAO (Food and Agriculture Organisation of the United Nations) (2016). System of Environmental-Economic Accounting for Agriculture, Forestry and Fisheries - SEEA Agriculture CONSULTATION DRAFT, available from: <https://unstats.un.org/unsd/ envaccounting/aff/2GC_Draft.pdf>, accessed 8 December 2016. 
UNMEA (UN Millennium Ecosystem Assessment) (2004). 'Living Beyond Our Means: Natural Assets and Human Well-Being: Statement from the Board', available from: <http://www. millenniumassessment.org/en/Products.BoardStatement>, accessed 15 October 2009.

Wackernagel, M. and Rees, W. (1996). Our Ecological Footprint. Philadelphia, PA: New Society Publishers.

Wackernagel, M., Onisto, L., Bello, P., Linares, A.C., Falfán, I.S.L., Garcıa, J.M., Guerrero, A.I.S. and Guerrero, M.G.S., (1999). National Natural Capital Accounting with the Ecological Footprint Concept, Ecological Economics, Vol. 29, No. 3, pp. 375-390.

Whiteman, G., Walker, B. and Perego, P. (2013). Planetary Boundaries: Ecological Foundations for Corporate Sustainability, Journal of Management Studies, Vol. 50, No. 2, pp. 307-336.

Worldwatch Institute (2013). State of the World 2013: Is Sustainability Still Possible?, Washington D.C.: Worldwatch Institute.

WWF (Worldwide Fund for Nature) (2016). Living Planet Report 2016, Switzerland: WWF. 